\title{
(IN)TRANSMISIBILIDAD DE LA ACCIÓN POR DAÑO MORAL EN ACCIDENTES DEL TRABAJO Y ENFERMEDADES PROFESIONALES Responsabilidad contractual del empleador en sede laboral
}

\author{
Gustavo Alejandro Fuentes Gajardo*
}

\begin{abstract}
RESUMEN: No hay duda que el trabajador vive menoscabado directamente en su dignidad por haber padecido un dolor, pesar, angustia y molestia psíquica a causa de un accidente del trabajo o enfermedad profesional por culpa o dolo de su empleador, será titular activo para ejercer la acción indemnizatoria por daño moral en sede contractual. La problemática surge en cuanto fallece. ¿Es transmisible a los herederos la acción de indemnización por daño moral? Desde el punto de vista del Derecho Laboral y de la Seguridad Social la doctrina no hay mayor claridad. Se analiza desde la doctrina del derecho común hasta la propia del derecho del trabajo, analizando jurisprudencia reciente para luego concluir en qué situaciones específicas es aplicable la tesis de la transmisibilidad y cuáles no. Se finaliza con propuestas de lege ferenda al respecto.
\end{abstract}

Palabras clave: Transmisibilidad, acción, daño moral, accidente, trabajo, enfermedad profesional, responsabilidad contractual, empleador.

ABSTRACT: There is no doubt that the living worker impaired in his or her dignity by suffered a pain, sorrow, grief and mental anguish caused by a work accident or occupational disease due to to negligence or fraud of his or her employer, will be the active titular to exercise the compensation action for moral damages based on contract. The problem arises when the worker dies. Is it transmissible to the heirs the action for compensation for moral damage? From the standpoint of Labor Law and Social Security the doctrine is no clear. It analyzes from the common law doctrine to its own labor law, examining jurisprudence before concluding that in which specific situations applies the theory of the transmissibility and in which not. It ends with proposals of lege ferenda about the matter.

Key words: Transmissibility, action, moral damage, accident, work, occupational disease, contractual responsibility, employer.

\section{INTRODUCCIÓN}

Del artículo 184 del Código del Trabajo se desprende el deber del empleador de velar por la vida y seguridad del trabajador ${ }^{1}$. A su vez, la Ley $\mathrm{N}^{\circ} 16.744$ establece la normativa sobre accidentes y enfermedades profesionales, fijando -entre otros derechos- como obligatorio un seguro social al verificarse este tipo de contingencia. En caso de que el accidente

\footnotetext{
* Licenciado en Ciencias Jurídicas y Sociales, Universidad Austral de Chile. Este trabajo forma parte de la Tesis para optar al grado académico de Licenciado en Ciencias Jurídicas y Sociales de la Facultad del mismo nombre.

${ }^{1}$ Su inciso primero prescribe la obligación de tomar las medidas necesarias para proteger eficazmente la vida y salud de los trabajadores. Dicha normativa se entiende incorporada a todo contrato de trabajo y, por tanto, es exigible frente a un incumplimiento.
} 
Gustavo Alejandro Fuentes Gajardo / (In)transmisibilidad de la acción por daño moral en accidentes del trabajo..

o la enfermedad se deba a culpa o dolo de la entidad empleadora o un tercero ${ }^{2}$, la víctima y las demás personas a quienes el accidente o enfermedad cause daño, podrán reclamar al empleador o terceros responsables, también las otras indemnizaciones a que tengan derecho, con arreglo a las prescripciones del derecho común, incluso el daño moral. Cabe la distinción entre víctima directa -trabajador-y víctimas por repercusión -familiares y otras personas según corresponda-. En caso de muerte del trabajador, los familiares podrán accionar contra el empleador de iure hereditatis como sucesor del fallecido -en sede contractual-o de iure propio por el daño que el fallecimiento les provocó -en sede extracontractual-. ¿Es transmisible a los herederos la acción de indemnización por daño moral? Antes del análisis doctrinario, jurisprudencial y dogmático, tengamos presente algunas generalidades.

En cuanto a la competencia por responsabilidad contractual derivada de accidentes y enfermedades profesionales ${ }^{3}$-incluyendo el daño moral ${ }^{4}$ - no hay duda que son los juzgados laborales los llamados a conocer y determinarla ${ }^{5}$. En cuanto a los herederos, la doctrina y jurisprudencia están contestes que estos opten por la responsabilidad contractual del empleador en un procedimiento ordinario laboral, sin embargo, no podrán solicitar la indemnización por daño emergente porque implicaría un pago doble ${ }^{6}$. A su vez, se ha aceptado mayoritariamente la indemnización del lucro cesante ${ }^{7}$. En cuanto al daño moral, no existe claridad en la transmisibilidad de dicha acción a los herederos. Lo que sí está claro es que del artículo 69 de la ley se desprende que siempre procederá la reparación del daño moral -contractual o extracontractual- resolviendo la discusión clásica del derecho chileno ${ }^{8}$ en cuanto a la procedencia de reparar el daño extrapatrimonial en sede contractual, ello como argumento de norma expresa ${ }^{9}$.

\footnotetext{
${ }^{2}$ Artículo 69 letra b) Ley No 16.744. sobre Accidentes del Trabajo y Enfermedades Profesionales.

${ }^{3}$ Cfr. DIEZ, J. "Víctimas directas y por repercusión en la responsabilidad civil derivada de accidentes del trabajo o enfermedades profesionales en nuestra jurisprudencia reciente: del problema de la competencia a las distorsiones sustanciales", en: Varas, J. y Turner, S. (coord.). Estudios de Derecho Civil. Jornadas Nacionales de Derecho Civil. Valdivia 2005. Santiago: LexisNexis, 2005, pp. 571-572.

${ }^{4}$ Cfr. CoRral, H. Lecciones de responsabilidad civil extracontractual. Santiago: Editorial Jurídica Chile, 2003, p. 254.

${ }^{5}$ Artículo 420 del Código del Trabajo. Hoy en día no se discute que el trabajador que sufre un accidente o enfermedad profesional y vive, será titular activo para ejercer las diversas acciones correspondientes en contra de su empleador, entre ellas, la de daño moral.

${ }^{6} \mathrm{~A}$ menos que se pruebe que los perjuicios sean mayores de los indemnizados por el seguro social.

${ }^{7}$ El cual sería la diferencia que soporten los herederos entre los ingresos originales previos a la muerte y la pensión del seguro social.

${ }^{8}$ Para mayor abundamiento sobre esta temática, se recomiēnda ver: Domínguez ÁGuILA, R. y Domínguez BenAvente, R. "Daño moral en la responsabilidad contractual. Ausencia de norma excluyente de su reparación", en Revista de Derecho N 196, pp. 154 y ss. Concepción: Universidad de Concepción, julio-diciembre, 1994.

9 Cfr. Gumucio, J. "Responsabilidad civil del empleador por daños derivados de Accidentes o Enfermedades profesionales de sus dependientes: Problemas que genera la teoría dualista en la legislación chilena en materia de competencia", en: Revista Laboral Chilena $\mathrm{N}^{\circ}$ 5, p. 68. Santiago, mayo de 1999. Se ha entendido por la doctrina que el presente artículo es pionero por cuanto hace referencia expresa al daño moral. En la citada ley se vislumbra el ánimo integrador del legislador y, en ese sentido, resulta clave tanto desde el punto de vista argumentativo, como desde el punto de vista cuantitativo. Véase CARDENAS, $\mathrm{H}$. "Daño moral por incumplimiento de contrato: un réquiem por una uniformidad jurisprudencial", en: Revista Chilena de Derecho, vol. $33 \mathrm{~N}^{\circ} 3$, p. 589 . Santiago: Pontificia Universidad Católica de Chile, 2006.
} 


\subsection{TESIS MAYORITARIA: TRANSMISIBILIDAD DE LA ACCIÓN POR DAÑO MORAL EN EL DERECHO COMÚN}

El problema de la transmisibilidad de la acción por daño moral surge frente a la posibilidad de ejercer dicha acción con la finalidad de conseguir indemnización de perjuicios ocasionados a la víctima inmediata, en aquellas situaciones en que el trabajador fallece sin haber intentado la acción correspondiente ${ }^{10}$. Ello, pues resulta común que el trabajador sufra aflicciones o dolores previos a su fallecimiento, por lo que se estaría frente a la pregunta de si pueden los herederos demandar el daño moral que haya experimentado la víctima antes de fallecer ${ }^{11}$.

La doctrina nacional tradicional ha seguido la tesis de la transmisibilidad relativa ${ }^{12}$, es decir, la necesaria distinción en cuanto a que los herederos no pueden ejercer dicha acción si la víctima del delito o cuasidelito ha fallecido instantáneamente, pues no logró incorporar en su patrimonio la acción y no pudo, consecuentemente, transmitirla ${ }^{13}$, en contraposición con la sobrevivencia de la víctima directa o inmediata, aun por breves instantes, pero que con posterioridad muere producto de las lesiones o por otra causa, pues allí sus herederos sí podrán incoar la acción ${ }^{14}$. Todo esto siguiendo el artículo 1097 de nuestro Código Civil ${ }^{15}$. Esta doctrina que acepta la transmisibilidad de la acción por daño moral a los herederos la siguen otros autores, especialmente J. Bidart que ha tratado esta cuestión de forma más detallada ${ }^{16}$. Por su parte, Rodríguez Grez sostiene la tesis de la transmisibilidad, incluyendo la mal llamada muerte instantánea, utilizando como argumento principal el artículo $19 \mathrm{~N}^{\circ} 1$ de la Constitución, entendiendo este derecho como la facultad de proyectarse en el tiempo, la vida como un bien en sí mismo, por lo que la tesis contraria, traería como consecuencia dejar de lado la vida en cuanto a bien valioso para nuestro ordenamiento jurídico ${ }^{17}$.

Por lo anterior, se puede afirmar que la tesis de la transmisibilidad de la acción ha sido aceptada tradicionalmente por nuestra doctrina y jurisprudencia mayoritaria, demostrado en diversos fallos ${ }^{18}$. Sin perjuicio, y como ya hemos visto, la jurisprudencia actual, es-

\footnotetext{
${ }^{10}$ Cfr. Walter, R. y Lanata, G. Régimen legal del Nuevo Proceso Laboral Chileno. Santiago: LegalPublishing, 2009 , p. 129.

11 Ibid.

12 Cfr. Domínguez, R. "Sobre la transmisibilidad de la acción por daño moral", en: Revista Chilena de Derecho. vol. $31 \mathrm{~N}^{\circ} 3$, p. 500. Santiago: Pontificia Universidad Católica de Chile, 2004.

${ }^{13}$ Cfr. Alessandri, A. De la responsabilidad extra-contractual en el Derecho Civil Chileno. Tomo II -2a edición-. Santiago: Ediar Editores Ltda, 1983, p. 468.

14 ALESSANDRI, A., op. cit. (n. 13), p. 469.

15 "Los asignatarios a título, con cualesquiera palabras que se les llame... son herederos: representan la persona del testador para sucederle en todos sus derechos y obligaciones transmisibles".

${ }^{16}$ Cfr. Domf́nguez, R. "Por la intrasmisibilidad de la acción de daño moral", en: VARAs, J. A. y TuRner, S. (coord.). Estudios de Derecho Civil. Jornadas Nacionales de Derecho Civil. Valdivia 2005. Santiago: LexisNexis, 2005, pp. 614-615.

${ }_{17}$ Cfr. Rodriguez, P. Responsabilidad Extracontractual. Santiago: Editorial Jurídica de Chile, 1999, pp. 366-367. Este último argumento ha sido fuertemente criticado por Ramón Dominguez. Véase DOMfNGUEZ, R. "Sobre la transmisibilidad... (n. 12), p. 501 . Se postula que no sería determinante en relación a decidir en cuanto a la transmisibilidad de la acción por daño moral.

${ }^{18} \mathrm{Cfr}$. DiEZ, J. "Vicrimas directas y por repercusión derivada de accidentes del trabajo o enfermedades profesionales en nuestra jurisprudencia reciente: del problema de la competencia a las distorsiones sustanciales”, en: Revista de Derecho $\mathrm{N}^{\circ} 214$, año LXXI, p. 74. Concepción: Universidad de Concepción julio-diciembre, 2003. Se citan los siguientes fallos: C. Santiago,
} 
Gustavo Alejandro Fuentes Gajardo / (In)transmisibilidad de la acción por daño moral en accidentes del trabajo..

pecialmente la de la Corte Suprema conociendo recursos de casación, ha optado por la tesis contraria.

Por su parte -y a pesar de desaprobar la transmisibilidad desde un punto de vista ético- la profesora Domínguez Hidalgo ha señalado que:

“...la transmisibilidad de la acción por daño moral no ejercitada por el causante no parece discutirse en la actualidad. Su carácter personalísimo no es uniformemente admitido, porque tiene un contendido económico evidente, ya que la reparación habrá de traducirse en indemnización dineraria, salvo los casos de otras formas de reparación, por ejemplo del derecho al honor, que además no excluyen la indemnización económica. Y, en definitiva, no hay objeciones técnicas para someterla al sistema general de transmisibilidad de los derechos y acciones del causante. En derecho comparado latino, es ésta una cuestión que en el presente ya no merece dudas y esa es la doctrina seguida en nuestro derecho" 19 .

\section{En palabras de Alessandri Rodríguez:}

"Tratándose de daño en las personas, esta acción también es transmisible, no en virtud del art. 2315, que no tiene aplicación en este caso, pues se refiere exclusivamente al daño en las cosas, sino de los principios generales que reglan la sucesión por causa de muerte. Los herederos representan la persona del difunto y le suceden en todos sus derechos y obligaciones transmisibles y el derecho de demandaxperjuicios por un delito o cuasidelito tiene este carácter, pues ninguna ley lo ha declarado intransmisible (arts. 951 y 1097)"20.

El profesor Barrientos Zamorano, analizando los ordenamientos jurídicos contempo-ráneos, ha dicho que se "... descarta la transmisibilidad iure hereditatis en los casos de muerte coetánea al accidente y la admite de ordinario, cuando la muerte no es simultánea..." 21 y por tanto el daño moral sufrido por la muerte, muerte que no puede ser sino un acto de vida, se transmite, agravándose por el conocimiento mismo de encontrar la muerte en un tiempo futuro e inminente 22 . Por su parte, el derecho español, expresado por Rafael Álvarez Vigaray, entiende que, al no existir norma alguna que prohíba la transmisibilidad de dicha

sentencia 23 mayo 2001, Rol 5.591- 2000, confirmada por C. Suprema, sentencia 6 septiembre 2001, Rol C. Suprema 2.6692001; sentencia 5 marzo 2004 dictada por el juez Manuel Muñoz Astudillo, Segundo Juzgado de Letras en lo Civil de Talcahuano, Rol 4.714-2002; y C. Concepción, 12 abril 2004, Rol 4016-2003.

19 Domf́nguez, C. El Daño Moral. Tomo II. Santiago: Editorial Jurídica de Chile, 2000, p. 731. Junto al argumento ético, desde el punto de vista técnico jurídico; y siguiendo al Derecho francés, la citada autora ha afirmado que si la víctima no había deducido la acción por daño moral antes de su fallecimiento, se ha sostenido que ella no es transmisible, trayendo, consecuentemente, un enriquecimiento sin causa.

${ }^{20}$ AlessandRI, A., op. cit. (n. 13), pp. 467-468.

ALESSANDRI, A., op. cit. (n. 13), p. 469.

21 BARRIENTOS ZAMORANO, Marcelo. "La transmisibilidad de la acción por daño moral en el Derecho privado europeo", en: La Semana Juridica, $\mathrm{N}^{\circ} 218,10$ al 16 enero de 2005 , p. 15.

${ }^{22}$ Cfr. ibid. 
acción, deberá aplicarse el principio de la transmisibilidad por causa de muerte. Apoya dicha posición Esther Gómez Calles, sin perjuicio de entenderla como excepción a la regla general de la intransmisibilidad ${ }^{23}$.

Como hemos podido ver, la doctrina anteriormente citada se ha pronunciado desde la esfera de la responsabilidad extracontractual. Desde un punto de vista contractual, la doctrina clásica del derecho francés, frente a procedencia de que los herederos puedan demandar y pedir la reparación corporal o moral sufrido por el causante, distingue, al igual que la posición seguida por Alessandri, en si la acción fue incoada o no por el difunto previamente a su muerte. En el primer caso, al igual que la doctrina nacional tradicional, no hay duda alguna que la acción se transmite a los herederos ${ }^{24}$. En el segundo caso, cuando la víctima no haya podido accionar antes de su muerte, se distingue, el perjuicio sufrido por la víctima antes de su muerte y el perjuicio resultante de la misma muerte. En cuanto al perjuicio anterior al fallecimiento se distingue, en primer lugar, si el perjuicio es material, originando un crédito para la sucesión, donde no existiría duda de su transmisibilidad, al no existir norma expresa que lo prohíba. En segundo lugar, en caso de un perjuicio moral sufrido por la víctima, "... El derecho francés antiguo, al reproducir una solución del derecho romano, se oponía a ello..." 25 , teoría la cual en la actualidad no tiene asidero y no se podría invocar para negar al heredero a demandar. Por tanto, concluye la doctrina francesa, "La acción de la víctima, para la reparación del perjuicio corporal de orden material o moral, o de un perjuicio moral cualquiera haya experimentado antes de su muerte, pasa, pues, a sus herederos" 26 .

En cuanto al perjuicio causado a la víctima por su fallecimiento, en el caso de muerte instantánea, acepta la tesis de la transmisibilidad pues "...en ese instante, por breve que haya sido, en que la víctima ya alcanzada no había muerto aún, en ese instante en que su patrimonio existía todavía, se origina el crédito de indemnización"27. Y con mayor razón, con una muerte posterior de la víctima, también se transmite la acción a los herederos, pues los herederos no demandan la reparación de perjuicio sufrido por una persona muerta, sino que "...la reparación del perjuicio sufrido por un ser viviente al morir"28.

\footnotetext{
${ }^{23}$ Cfr. Ramírez, M. Transmisibilidad de la acción por daño moral. Un estudio comparativo entre Chile y España. Tesis. Talca: Universidad de Talca, 2004, pp. 46-47.

${ }^{24}$ Cfr., MAZZAUD, H. y TUNC, A. Tratado teórico y práctico de la responsabilidad civil delictual y contractual. Tomo II, volumen II. Buenos Aires: Ediciones Jurídica Europa-América, 1978, pp. 535 y ss.

${ }^{25}$ Mazzaud, H. y TunC, A., op. cit. (n. 24), p. 537. Los connotados juristas citan del Derecho francés antiguo a Jousse: "En esta especie de acción se trata menos de reparar un daño recibido que de vengarse de una afrenta; el que muera sin quejarse de ella se considera, por su silencio, que ha perdonado la ofensa que se le había inferido".

${ }^{26}$ Mazzaud, H. y TUNC, A., op. cit. (n. 24), p. 539.

${ }^{27}$ Mazzaud, H. y TunC, A., op. cit. (n. 24), p 541.

${ }^{28}$ Mazzaud, H. y TunC, A., op. cit. (n. 24), p. 541.
} 


\section{TESIS MINORITARIA RECIENTE: POR LA INTRANSMISIBILIDAD DE LA ACCIÓN}

Por otro lado, existe una reciente aceptación de la tesis de la intransmisibilidad de la acción indemnizatoria por daño moral, la cual, además, ha tenido asidero en la jurispruden$\mathrm{Cia}^{29}$

Por la intransmisibilidad de la acción, Domínguez Águila es el principal representante en nuestra doctrina. Para el referido autor, los derechos o bienes de la personalidad están unidos al titular, desaparecerían con él y por tanto serían intransmisibles. Es por ello que forjar la transmisibilidad de la acción por daño moral implica aceptar que el interés a reparar perdura al causante por sus herederos, lo cual iría mucho más allá de su propia justificación ${ }^{30}$. Los seguidores de la transmisibilidad incurrirían en una contradicción evidente, pues por un lado aceptarían la transmisibilidad siguiendo la regla de la continuidad de los herederos, pero por otra parte se cierran a la posibilidad de transferencia de dicha acción por actos entre vivos, por tratarse de un derecho personalísimo, ello por lo absurdo que sería dicha situación ${ }^{31}$.

Si bien la tesis de la reparación del daño moral se ha extendido, teniendo asidero en nuestros tribunales, quienes propugnan la intransmisibilidad señalan que la transmisibilidad de la acción por daño moral no se ha extendido. Para negar la transmisibilidad, según esta doctrina, existen dos argumentos. El primer argumento se refiere a la naturaleza del daño moral, pues dicho daño no perdería la esencia de derecho personalísimo. El segundo argumento, dice relación con la función de la indemnización de perjuicios, la cual busca, por su naturaleza, la compensación de un mal sufrido personalmente, el cual no sería transmisible ${ }^{32}$.

Es por ello que esta doctrina al rechazar la transmisibilidad, propone que los herederos opten por indemnización del dańo reflejo y actúen en calidad de iure propio ${ }^{33}$. Igual opinión plantea Leslie Tomasello Hart ${ }^{34}$.

Domínguez Águila, citando a Cadiet, expresa que se “... desnaturaliza la noción de daño moral y se desvía la reparación de su finalidad, admitiendo la transmisión sucesoral del crédito de reparación" ${ }^{35}$. Sin mencionar que de acuerdo a los órdenes de sucesión que plan-

\footnotetext{
${ }^{29}$ Cfr. Diez, J. "Responsabilidad civil derivada de accidentes del trabajo y enfermedades profesionales: aspectos relevantes de su regulación y operatoria actual", en: Revista de Derecho $\mathrm{N}^{\circ}$ 21, pp. 181-182. Valparaíso: Pontificia Universidad Católica de Valparaíso, $2^{\circ}$ semestre, 2008. Se cita a favor de la transmisibilidad: Corte de Apelaciones de Concepción, del 15 de diciembre de 2004, rol N $\mathrm{N}^{\circ}$ 2074-2004 y del 26 de abril de 2006, rol N ${ }^{\circ} 4825-2003$. A favor de la intransmisibilidad, Corte de Apelaciones de Santiago, del 2 de noviembre de 2005, rol Nं² 27271-2002.

${ }^{30}$ Cfr. DOMINGUEZ, R., "Sobre la transmisibilidad... (n. 12), p. 504.

31 DOMINGUeZ, R., "Sobre la transmisibilidad... (n. 12), pp. 504-505.

32 Cfr. BARros, E. Tratado de responsabilidad extracontractual. Santiago: Editorial Jurídica de Chile, 2006, pp. $945-946$.

33 BARROS, E. op. cit. (n. 32), p. 947.

34 Cfr. Ramirez, M., op. cit. (n. 23), p. 48. Postula Leslie Tomasello Hart, desde el derecho comparado, que la acción por indemnización por daño moral es totalmente inadmisible por ser de carácter personal y, por lo mismo, no cabría la posibilidad de aceptar que un sucesor por causa de muerte ejerciere la acción del titular.

35 CADIET, L. "Le préudice d' argrément", $N^{\circ} 362$, Potier, 1983, citado en: DomínGUEZ, R. "Comentarios de Jurisprudencia 1. La acción por daño moral es intransmisible a los herederos de la víctima directa”, en: Revista de Derecho $\mathrm{N}^{\circ} 219-220$, año LXXIV, p. 262. Concepción: Universidad de Concepción, enero-diciembre, 2006.
} 
tea nuestro ordenamiento jurídico, en último lugar y no por ello menos importante, el artículo 995 del CC contempla al Fisco, a falta de todos los herederos abintestato designados en los artículos que le preceden, presentándose la hipotética situación que el Estado accione por el daño moral que una persona no alcanzó a demandar ${ }^{36}$.

A ello se suma el cuestionamiento ético que plantea la profesora Domínguez Hidalgo, al darse la situación que una persona pueda obtener provecho a costa de sufrimiento de ajeno. Señala que en cuanto a la transmisibilidad de una acción por daños materiales tiene razonamiento lógico pues “...se trata nada más que del mecanismo común de la sucesión hereditaria, referida al patrimonio del de cujus. Pero que un tercero, por heredero que sea, pueda beneficiarse del daño moral ajeno no es una conclusión que se imponga fácilmente en el plano ético" 37 . Si la víctima no había deducido la acción por daño moral antes de su fallecimiento, además de señalarse que existe enriquecimiento $\sin _{\text {causa }}{ }^{38}$, no podría cederse y por tanto sería intransmisible, tratándose de derechos personalísimos unidos a su titular ${ }^{39}$.

El admitir la transmisibilidad, bajo el pretexto de la protección de la persona y su dignidad, sería llevar el principio de la continuación del causante por sus herederos a extremos impropios, dando paso y apoyando la tesis de la mercantilización exagerada del tema de la responsabilidad civil ${ }^{40}$. A modo de síntesis, la doctrina que aboga por la intrasmisibilidad de la acción por daño moral a los herederos del trabajador señala que no existe trascendencia alguna en determinar si la víctima falleció instantáneamente o no, pues, por su naturaleza y su fin, la reparación del daño moral es personalísima y concluyentemente, no transmisible ${ }^{41}$.

De llegar a imponerse la tesis de la intransmisibilidad ${ }^{42}$, se eliminaría la posibilidad de accionar a través de tribunales laborales por parte de los hijos, cónyuge sobreviviente, padres o hermanos, a causa de la muerte del trabajador producto de un accidente del trabajo o una enfermedad profesional ${ }^{43}$.

\section{4. (IN)TRANSMISIBILIDAD EN EL ORDENAMIENTO JURÍDICO LABORAL CHILENO}

Los causahabientes del trabajador fallecido que actúen en calidad iure hereditatis en la búsqueda de una responsabilidad contractual de competencia laboral no lo hace en ningún

\footnotetext{
${ }^{36}$ Domínguez Águila cita a Mariano YzQuiERDo TOLSADA, el cual señala que "No creo yo que le Estado nos ame tanto como para considerarse perjudicado con nuestra muerte", en su obra Sistema de Responsabilidad Contractual y Extracontractual. Madrid: 2001, p. 378. Para todo Domínguez, R., "Comentarios de Jurisprudencia... (n. 35), p. 260.

37 DomíngueZ, C., op. cit. (n. 19), p. 731.

${ }^{38}$ Domf́ngueZ, C., op. cit. (n. 19), p. 730.

39 Ibid.

40 Cfr. DomfNGUEZ, R., "Sobre la transmisibilidad... (n. 12), p. 513.

${ }^{41}$ Cfr. Para todo DomíngueZ, R., "Comentarios de Jurisprudencia... (n. 35), p. 262.

42 Por la intransmisibilidad, existen sentencias que han argumentado que la reparación del dafio moral tiene por objeto la compensación del mal soportado personalmente por la víctima, armonizado con el tenor del artículo 88 de la Ley $\mathrm{N}^{\circ} 16.744$, norma la cual establece que los derechos por la presente ley son personalísimos e irrenunciables. Ver: DIEZ, J., "Responsabilidad civil... (n. 29), pp. 182-183. El autor alude a fallos de la Corte Suprema, 27 de junio de 2007, rol N 309-2006, C.S. 27 de noviembre 2007, rol N 6196-2006 y Corte de Apelaciones de Concepción 12 de septiembre de 2007, rol .N $423-2007$.

${ }^{43}$ Cfr. ibid.
} 
Gustavo Alejandro Fuentes Gajardo / (In)transmisibilidad de la acción por daño moral en accidentes del trabajo...

caso accionando por sus daños propios ${ }^{44}$. Ya analizamos la procedencia del lucro cesante o daño emergente y su transmisibilidad. Nos atañe analizar la acción por daño moral y su transmisión cuando el trabajador no alcanzó a incoar en vida.

La doctrina que acepta la tesis de transmisibilidad de la acción por daño moral ${ }^{45}$ a los herederos, parte de la premisa que la acción de indemnización emana del contrato de trabajo y pertenece exclusivamente al trabajador víctima del accidente del trabajo o a quienes le sucedieren en sus derechos y que, por lo mismo, no cabría la posibilidad de que terceras personas ajenas al trabajador o a la sucesión recurran en esta instancia en alegando dicha calidad $^{46}$.

Dentro de la titularidad de la acción de reparación, es del todo claro que el trabajador accidentado o afectado por una enfermedad profesional es titular de la acción de reparación de los perjuicios por ser parte de la relación laboral, mediante un contrato de trabajo ${ }^{47}$. Dejando de lado esta evidente situación, Gumucio y Corvera señalan que si las acciones han sido intentadas por el trabajador antes de su fallecimiento, no hay objeción alguna a la transmisión. Tampoco se objeta la transmisión si las acciones no han sido intentadas en vida de la víctima si se trataren de perjuicios sufridos por el trabajador antes de su muerte. La verdadera problemática surge cuando los herederos reclaman perjuicios derivados de la muerte misma de la víctima, cuando es instantánea ${ }^{48}$.

Esta doctrina a favor de la transmisibilidad, postulan que “...la acción indemnizatoria emana del contrato de trabajo y, por lo mismo, pertenece exclusivamente al trabajador víctima del accidente del trabajo o a quienes le sucedan en sus derechos" ${ }^{49}$. Es por ello que concluyen que no cabe a terceras personas ajenas al trabajador o a su sucesión la posibilidad de recurrir para obtener dicha reparación del daño sufrido por el trabajador. Con esta afirmación, quedaría fuera el conviviente del trabajador o trabajadora fallecida ${ }^{50}$. Desde ya surge de lege ferenda contar con un régimen especial de responsabilidad que incluya competencia única, claridad en cuanto a la prescripción, carga probatoria a favor del trabajador o sus herederos y que incluya nuevas situaciones de hecho ${ }^{51}$, como ya lo ha incorporado la

\footnotetext{
${ }^{44}$ Cfr. Dominguez, R. "Comentarios de Jurisprudencia 1. Competencia civil para el conocimiento de la acción indemnizatoria del daño moral sufrido por causahabientes del trabajador", en: Revista de Derecho $\mathrm{N}^{\circ} 211$, año LXX, p. 261. Concepción: Universidad de Concepción, enero-junio, 2002.

45 Lo complejo es el hecho que no existe posibilidad cierta de saber con algún grado de exactitud que el daño moral existió y fue experimentado por la víctima antes de fallecer. Además existirían, según parte de la doctrina laboralista, razones de peso para afirmar que tratándose del dolor o sentimiento de una persona, la acción sería personalísima. Para esto se recomienda ver WALTER, R. y LANATA, G., op. cit., (n. 10), p. 131.

${ }^{46}$ Cfr. Gumuclo, J., op. cit. (n. 9), p. 65.

47 Por tanto podrá demandar al empleador por la responsabilidad que le cabe cuando este último no ha tomado las medidas necesarias para velar por la vida o seguridad de sus dependientes.

48 Ibid.

49 GUMUCIO, J., op. cit. (n. 9), p. 65.

50 No obstante ello, se puede accionar de perjuicios en sede extracontractual frente a un tribunal por los daños propios. Sus efectos: régimen de responsabilidad distinto con conocimiento de un tribunal no especializado en la materia; plazo de prescripción de cuatro años; onus probandi en quien alega.

51 Comparando las personas que contraen matrimonio en los dos últimos censos poblacionales realizados por el Instituto $\mathrm{Na}$ cional de Estadísticas, en los años 1992 y 2002, el porcentaje de personas que contraen matrimonio se contrajo de un $51 \%$ a un 42,2\%. Ver: Censo Poblacional y Vivienda, año 2002, Instituto Nacional de Estadísticas
} 
Ley $\mathrm{N}^{\circ} 16.744$ al incluir a la conviviente que sea madre de hijos del trabajador, otorgándole una pensión de sobrevivencia específica ${ }^{52}$.

La concatenación de normas legales para afirmar a favor de la transmisibilidad, se inicia con el artículo 184 del CT, el cual contempla el deber de protección del empleador, norma que se entiende incorporada al contrato de trabajo. Al producirse un accidente o enfermedad profesional por culpa o dolo del empleador -de acuerdo al art. 69 letra b) de la Ley $\mathrm{N}^{\circ} 16.744-$ se faculta a la víctima y a las demás víctimas a quienes el accidente o enfermedad cause daño de accionar de perjuicios también las otras indemnizaciones a que tengan derecho, con arreglo a las prescripciones del derecho común, incluso el daño moral. Por lo que, en caso de fallecimiento del trabajado, y entendiendo que los herederos son los representantes del causante en todos sus derechos y obligaciones, en concordancia con el artículo 1097 del Código Civil, la titularidad de la acción pertenecería a los herederos del trabajador.

Contraria a la postura de la transmisibilidad, la profesora Verdugo Ernst, al analizar la reforma incorporada al artículo $420 \mathrm{del} \mathrm{CT,} \mathrm{entiende} \mathrm{que} \mathrm{son} \mathrm{de} \mathrm{competencia} \mathrm{laboral} \mathrm{la}$ responsabilidad del empleador en los accidentes o enfermedades profesionales y afirma que el artículo 69 de la Ley $\mathrm{N}^{\circ} 16.744$ es exclusivamente para accionar por responsabilidad extracontractual ${ }^{53}$.

Que al referirse a la responsabilidad contractual, la competencia del tribunal laboral se circunscribe "... a los juicios en quienes tiene calidad de trabajadores..." 54 y que la letra f) del artículo 420 del CT cumple el propósito de zanjar las diferencias en los tribunales del trabajo y en los tribunales superiores frente a la problemática de la competencia cuando conozcan de indemnizaciones de perjuicios "...entabladas por la viuda y/o hijos de un fallecido por accidente del trabajo o enfermedad profesional, con quienes el empleador no ha tenido relación laboral alguna y por ende tampoco las obligaciones de higiene y seguridad en el trabajo conforme a la normativa vigente" 55 . Agrega además, que cuando el trabajador afectado por un accidente o enfermedad profesional quiera accionar de perjuicios por la culpa o dolo del trabajador, dicha responsabilidad es delictual o cuasi delictual y que los herederos del trabajador fallecido, no son titulares de la acción de reparación por vía contractual. Y que en consecuencia, "...los derechos en referencia no pueden ser transferidos a una tercera persona o transmitidos por causa de muerte. Solo lo puede ejercer el titular único y exclusivo, en caso de haber verificado los supuestos previstos por la ley como determinante de un estado de necesidad legalmente protegido" 56 . Conclusión a la que llega que, es menester señalar, se contradice y no consideramos del todo lógica y fundamentada, como veremos más adelante.

Fundamenta la intransmisibilidad a los herederos del trabajador, en que la Ley $N^{\circ} 16.744$ está compuesta por derechos de carácter subjetivo público y que "...se caracteri-

\footnotetext{
52 Así lo contempla el artículo 45 de la ley en comento.

${ }^{53}$ Cfr., Verdugo ERNST, Lucía. "La responsabilidad del empleador en los accidentes del trabajo o enfermedades profesionales", en: Revista Laboral Chilena $\mathrm{N}^{\circ} 1$, enero 1997, pp. 65 y ss.

${ }^{54}$ Verdugo ERNST, Lucía, op. cit. (n. 53) p. 68.

55 Ibid.

56 VERDUGO ERNST, Lucía, op. cit. (n. 53) p. 67.
} 
zan por ser personalísimos, de modo que los derechos a las prestaciones de seguridad social son todos personalísimos, sin excepción" 57 . Y llega a la conclusión que no pueden ser transmitidos ni transferidos a terceras personas, pues solo puede ser ejercido por el titular, único y exclusivo. Pero arriba a esa conclusión con la premisa errónea que el artículo 69 de la Ley $N^{\circ} 16.744$ se refiere exclusivamente a responsabilidad extracontractual.

Los derechos contemplados en la Ley $\mathrm{N}^{\circ} 16.744$, según la autora, tienen un carácter de derechos subjetivos públicos y consecuentemente son personalísimos, intransmisibles e irrenunciables. Sin embargo, lo presupuestado en el Código del Trabajo, es necesario señalar que ha sido la propia jurisprudencia la que ha sostenido que el empleador tiene un deber de protección/obligación de seguridad, la cual también es una obligación legal derivada de normas de orden público ${ }^{58}$, expresado principalmente en el artículo 184 del CT, donde se desprende que el empleador debe velar por la vida y seguridad del trabajador. Su inciso primero prescribe la obligación de tomar las medidas necesarias para proteger eficazmente la vida y salud de los trabajadores. Dicha normativa se entendería incorporada a todo contrato de trabajo y es por tanto exigible frente a un incumplimiento, como su contenido ético ${ }^{59}$. Y que dicha obligación, por encontrarse en el Código del Trabajo, además de ser una obligación de carácter legal, no tiene la naturaleza de derecho subjetivo público, haciendo procedente la acción ${ }^{60}$.

A pesar de todo lo anterior, existe otro sector de la doctrina, prescindiendo de la discusión en cuanto a la transmisibilidad o intrasmisibilidad, minoritaria, que afirma que para lograr la finalidad de protección a los trabajadores y hacerlo más eficiente socialmente, habría que ampliar el seguro social y eliminar la responsabilidad civil, pues, para esta última responsabilidad, hoy en día, la regla de la negligencia es mucho más eficiente que la responsabilidad objetiva ${ }^{61}$.

Lo que no podemos negar, es que frente al tema de la (in)transmisibilidad de la acción, resulta cada vez más frecuente que los causahabientes ejerzan la acción de iure hereditatis ante tribunales de competencia laboral por el daño moral que el trabajador fallecido haya experimentado y transmitido al momento de fallecer ${ }^{62}$. Esto por la relación de los artículos 184 y 420 del CT junto con la ley de accidentes del trabajo y enfermedades profesionales.

\footnotetext{
57 Ibid.

${ }^{58}$ Cfr. DIEZ, J. "La culpa del empresario por accidentes del trabajo: modernas tendencias jurisprudenciales", en: BARAONA, J. y ZELAYA, P. (editores). La responsabilidad por accidentes del trabajo. Cuadernos de Extensión Juridica, $\mathrm{N}^{\circ} 10$, p. 95 . Santiago: Universidad de los Andes, 2005.

59 Ibid.

${ }^{60}$ En este mismo sentido, ver: GAY, A. y GEISSE, C. Responsabilidad civil del empleador por accidentes del trabajo. Tesis. Valdivia: Universidad Austral de Chile, 2000.

${ }^{61}$ Cfr. LAGOS, O. “¿Hacia una objetivación jurisprudencial de la responsabilidad patronal? Criterios para evaluar sus consecuencias", en: GUZMAN, A. (editor científico). Estudios de Derecho Civil III. Valparaíso 2007. Santiago: LegalPublishing, 2008, p. 855 .

${ }^{62}$ Cfr. DIEZ, J., "Víctimas directas... (n. 18), p. 575.
} 


\section{JURISPRUDENCIA RECIENTE DE ACCIDENTES Y ENFERMEDADES PROFESIONALES}

A continuación se exponen y analizan algunos fallos que tratan la transmisibilidad de la acción por daño moral en materia laboral.

1) Corte Suprema, Rol N4.794-0963, conociendo de casación, señala que es de competencia del juez laboral la indemnización por daño moral por el accidente del trabajo.

2) Herederos accionan por responsabilidad contractual. La Corte Suprema, rol No 3.337-08 $8^{64}$, declara la incompetencia del juez a $q u o^{65}$, el cual había acogido una demanda a favor de los demandantes que actuaron de iure propio. Dicha demanda a su vez había sido confirmada por la Corte de Apelaciones de Santiago, en su sentencia de 7 de mayo del $2008^{66}$.

El empleador, al recurrir de casación, señala que la acción de los herederos fue deducida a título propio por el daño patrimonial y moral que la muerte del trabajador causó en ellos, no teniendo vínculo alguno con la parte demandante, denominándola "víctima por repercusión o rebote" pues no estarían alegando en su calidad de herederos del causante, siendo procedente la acción de responsabilidad extracontractual con competencia del juez civil. La CS acogió el recurso. Podemos visualizar en primer lugar la confusión producto de una falta de certeza jurídica por parte de la demandante, al no dejar en claro si se accionaba por daño propio o en calidad de herederos del trabajador fallecido. También se evidencia poca acuciosidad por parte del tribunal a quo y ad quem, al no pronunciarse sobre el fondo ${ }^{67}$ de la discusión, cual es, la transmisibilidad de la acción por moral a los herederos. Sin perjuicio de lo anterior, es interesante el voto de disidente del Ministro Brito, pues el tribunal laboral sería competente para conocer la demanda, pues se evidencia que la demandante acciona por el incumplimiento del artículo 184 del CT, y que en aplicación del 420 letra f) del

\footnotetext{
63 Santiago, 20.06.08. Sergio Anthony Alvarado Flores con Julio Puebla Fuentes. No LegalPublishing: 42370. Si bien no se discute la (in)transmisibilidad por cuanto el trabajador es quien acciona, es importante señalar la responsabilidad contractual y el daño moral. El daño moral provocado al trabajador se avaluó en la suma de $\$ 50.000 .000$.

${ }^{64}$ Santiago, 20.08.08. Yesenia Cuevas Alarcón con Industria Forestal Nacional. N LegalPublishing: 39580.

${ }^{65}$ Se demanda al empleador por la muerte del cónyuge y solicita indemnización por el daño moral sufrido por ella e hijos a causa de la muerte del trabajador, mientras aquel se desempeñaba en labores de electricista. El empleador fue condenado a pagar $\$ 100.000 .000$, por concepto de daño moral. Lo cual fue confirmado por la Corte de Apelaciones.

66 Santiago, 07.05.08, Corte de Apelaciones $23.142007 . \mathrm{N}^{\circ}$ LegalPublishing: 39179.

67 Sin embargo, el considerando tercero de la sentencia de primera instancia señala que “... la acción deducida por la víctima y sus herederos debe ser calificada como responsabilidad contractual porque ella se funda en el incumplimiento del empleador de las obligaciones que les imponen los artículos 184 y 210 del Código del Trabajo las que forma parte de los respectivos contratos de trabajos con arreglos al artículo 1546 del Código Civil; la responsabilidad deriva entonces de un vínculo contractual previo y por ende se encuentra dentro de la competencia entregada a los Tribunales Laborales...". Ello coincide con el voto disidente del ministro Brito de la Corte Suprema. De todas formas no se hacen cargo ni tampoco se pronuncian sobre la existencia de la transmisibilidad de la acción por daño moral.
} 
Gustavo Alejandro Fuentes Gajardo / (In)transmisibilidad de la acción por daño moral en accidentes del trabajo...

mismo Código, faculta a los herederos de accionar, pues al momento de la muerte del trabajador, se encontraba vigente el contrato de trabajo ${ }^{68}$.

Interesante es el pronunciamiento que en esta causa hace la misma Corte de Apelaciones estableciendo una regla de atribución de competencia material ${ }^{69}$. Sin perjuicio de lo anterior, y como ya señalábamos, la Corte Suprema acogió la tesis de la intransmisibilidad de forma implícita pronunciándose sobre la competencia.

3) Que en otra jurisprudencia, la Corte de Apelaciones de Copiapó ${ }^{70}$ reafirma la competencia laboral frente indemnizaciones provenientes de un accidente laboral, siempre que sea la propia víctima o sus sucesores.

4) La Corte de Apelaciones de Concepción, rol 423200771, se hace cargo de la transmisibilidad y afirma el carácter de personalísima de la acción ${ }^{72}$. En primera instancia el juez a quo acoge la demanda interpuesta por los herederos y condena al empleador por los daños propios a los herederos ocasionados por el incumplimiento del contrato de trabajo. Dicho error es refrendado por la Corte, realizando además, un análisis doctrinal y jurisprudencial que la lleva a concluir la acción establecida en el artículo 69 de la Ley $\mathrm{N}^{\circ} 16.744$ es personalísima e intransmisible ${ }^{73}$. Este pronunciamiento por parte de la Corte de Apelaciones de Concepción es de suma importancia por cuanto, a diferencia de los anteriores casos, se pronuncia expresamente sobre la transmisibilidad del daño moral a los herederos del trabajador y realiza un análisis de fondo. Para ello comienza interpretando armónicamente los artículos 88 y 69 letra b) de la Ley $\mathrm{N}^{\circ} 16.744$, concluyendo que los derechos concedidos por la ley, entre los cuales se encuentra el prescrito por el artículo 69, son de carácter personalísimo e irrenunciable, dando a entender que la acción por daño moral deviene en personalísima. En el considerando treinta y dos alude a la naturaleza misma del dańo moral per se está unido a su titular, personalísimo, tornando el daño moral a la acción de per-

\footnotetext{
${ }^{68}$ A similar razonamiento llega el tribunal a quo pronunciándose a los daños propios de los sucesores provenientes del quiebre de la relación laboral.

${ }^{69}$ Esta regla sujeta el conocimiento de la acción a la materia de que se trata y no a la calidad de las personas que la ejercen, resultando competente el tribunal para conocer de la acción de indemnización de perjuicios interpuesta por la cónyuge del trabajador fallecido en el accidente, puesto que la responsabilidad que se pretende hacer efectivà es la derivada de la obligación de seguridad que pesa sobre el empleador -artículo 184 del CT- que tiene un carácter legal antes que contractual (considerandos $1^{\circ}$ y $\left.3^{\circ}\right)$.

70 Rol 193.2008. 29.07.08. N LegalPublishing: 39515. Sergio Isaac Pino Puentes con A and A Ingeniería Mecánica Integral Limitada y otros.

${ }^{71}$ Concepción, 12 de diciembre de 2007, Corte de Apelaciones de Concepción, 423 2007. Elizabeth del Carmen Huentemil Fuentes y otros con Agro Inversiones S.A. N LegalPublishing 37966.

72 Señala el considerando quinto que el trabajador sufrió un accidente laboral falleciendo por traumatismo torácico completo, aplastado por máquina pesada; participaba junto a otras personas en el desmontaje de un evaporador de frío, el cual se sostenía mediante un tecle con una cadena de amarre para poder ser retirado. Se cortó la cadena de amarre y cayó el equipo hacia el frente sobre el trabajador aplastándolo, ante lo cual se trata de levantar la máquina sin conseguirlo, lográndolo solo diez minutos después de ocurrido el hecho. En sentencia se acoge el daño moral por la suma de $\$ 30.000 .000$.

73 “... no se transmite jamás a los herederos; y que la finalidad de la indemnización por daño moral es eminentemente compensatoria del mal sufrido personalmente por la víctima, cabe concluir que la acción de indemnización por daño moral de la cual es titular la víctima directa de un accidente del trabajo es intransmisible a sus herederos". -Considerando treinta y cinco--
} 
juicios en intransmisible citando doctrina laboralista ${ }^{74}$ y civilista $^{75}$. Complementando esta visión doctrinaria, dicha Corte hace alusión a dos recientes fallos similares de la Corte Suprema, roles 309-0676 y 6.196-0677.

5) Corte Suprema, rol $4232007^{78}$. Si bien en este caso se pronuncia a favor de la parte demandante, nuevamente no hace alusión a la (in)transmisibilidad de la acción interpuesta por el cónyuge sobreviviente que actuó como sucesor hereditario del trabajador fallecido ${ }^{79}$. La Corte de Apelaciones revocó el fallo de primera instancia y obligó a pagar al empleador por los daños propios de la parte demandante ${ }^{80}$.

\footnotetext{
74 Para sostener lo anterior, la Corte cita doctrina laboralista, como a la profesora Lanata quien señala que "... no existe la posibilidad cierta de constatar con exactitud la existencia del dańo moral experimentado por la víctima antes de fallecer... tratándose del dolor o sentimientos de una persona, la acción es personalísima. Distinta es la situación que se produce en el caso de que la víctima haya alcanzado a intentar la acción, pues ya cuantificó el daño experimentado..." agregando que "...si aceptáramos la tesis de ... la transmisibilidad de la acción destinada a reparar el daño moral, los herederos estarían demandando, como se dijo, el dolor del trabajador fallecido, por lo que resulta forzoso concluir que se estaría frente a una responsabilidad de origen contractual, aunque quienes demandan, obviamente, son los herederos", en: LANATA, G. El contrato de Trabajo como negocio juridico en la Legislación Chilena. Tesis de Magíster. Argentina: Universidad Nacional de Rosario, 2007, p. 203.

75 En cuanto a la naturaleza misma del daño moral "Nada impide que los herederos ejerzan las acciones iure propio por los daños reflejos que se siguen de la muerte de una persona, pero no pueden fundar legítimamente su acción en la aflicción del causante". Véase BARROS, E., op. cit. (n. 32), pp. 945-946. También se cita a la profesora Domínguez quien señala que "Sin embargo, si la víctima no habia deducido la acción por daño moral antes de su fallecimiento, se ha sostenido que ella no es transmisible y menos podria cederse. Existiria entonces un enriquecimiento sin causa...", continúa, "... siendo el daño moral el que se causa a sentimientos de afección o, más generalmente, a derechos de la persona, la acción para obtener que sea reparado es personalisima, como lo son tales derechos, y por lo mismo va unida solo a la persona de su titular". Véase DOMfNGUEZ, C., op. cit. (n. 19), p. 730. 76 27.06.07. "debido a que la referida pretensión de reparación, en cuanto se sustenta en el sufrimiento moral de la víctima de un accidente del trabajo, por ser personalísima e intransmisible, no puede ser deducida por otro que no sea su titular y en el evento que el afectado haya fallecido, la acción por la indemnización de su padecimiento espiritual y aflicción, no se transmite al patrimonio de sus herederos"

77 27.11.08. La acción es personalísima “...aunque exista entre esa acción y el resarcimiento pretendido, que es de carácter pecuniario, un estrecho e indesmentible vínculo, por cuanto este último se genera y justifica en la aflicción del trabajador afectado, lo que le imprime el carácter de personalísima a la acción de que se trata, el que no logra desvirtuarse con el hecho que dé lugar a un crédito en dinero, pues aun integrando dicho elemento patrimonial, el sentido y contenido de la pretensión cuestionada sigue inalterable, ya que lo que ella persigue es compensar el mal soportado por la víctima, personalmente... de esta manera, el objetivo de resarcimiento, solo se cumple, entonces, cuando la reparación es entregada al que padeció el dolor, la molestia o aflicción en sus sentimientos o facultades espirituales, conclusión que, además, armoniza con el tenor del artículo 88 de la Ley $16.744 \ldots .$.

${ }^{78}$ Santiago, 06.12.07. Fabiola Angélica Hidalgo Riffo con Daniel Madariaga Salas; Tejas de Chena S.A. N LegalPublishing: 38031-2007.

${ }^{79}$ En primera instancia, se rechazó la demanda, puesto que el juez a quo llegó a la conclusión que el accidente sufrido por el trabajador, fue producto de una acción imprudente o indebida del mismo. El trabajador se encontraba en el foso del taller mecánico, desmontando un motor y desconectando mangueras de alimentación de bencina, para asistir un vehículo. Se reventaron las mangueras ocasionando chispas, empapándose su cuerpo de bencina incendiada por la combustión. El trabajador arrancó del taller hacia el patio, tratando de impedir el avance del fuego con sus propias manos, hasta que se lanzó a un charco de aguas lluvias, revolcándose a fin de apagar el fuego de la hoguera que lo consumía, quemándose el $65 \%$ del cuerpo y falleciendo a los cinco días siguientes.

${ }^{80}$ Rol No 1.3432006 , con fecha 26 de diciembre de 2006. Al contratista se le condenó a la suma única de $\$ 10.000 .000$ a título de daño moral experimentado por dichas demandantes con motivo de la muerte del trabajador, ocurrida con motivo del accidente del trabajo.
} 
Este caso evidencia un carente pronunciamiento, tanto por las partes como por el tribunal de primera y segunda instancia, como también por parte de la Corte Suprema ${ }^{81}$ en cuanto a la (in)transmisibilidad de la acción, donde inclusive se pasa por alto y se termina resarciendo por los daños producidos a los herederos, pero en calidad de iure propio, y no como inicialmente se planteó la demanda original, en su calidad de iure hereditatis.

6) Corte Suprema, rol 6196-0682. Recoge la tesis de la intransmisibilidad argumentando que la acción es de naturaleza personalísima ${ }^{83}$ no pudiendo alterar la naturaleza de la pretensión, cual es, compensar el mal soportado por la víctima personalmen$\mathrm{te}^{84}$. Por lo tanto, el resarcimiento no sería sancionatorio ${ }^{85}$. La parte demandante ${ }^{86}$, al recurrir de casación en el fondo, argumenta que luego del accidente, el trabajador permaneció consciente, por tanto, aplicando el artículo 69 de la Ley $\mathrm{N}^{\circ} 16.744$, adquiriría el derecho, el cual se incorpora al patrimonio para ser indemnizado por los daños sufridos. Dicho derecho es el que transmite a sus herederos, de acuerdo al principio recogido por el artículo 1097 del CC, ya que si bien el dolor es personalísimo, la indemnización a que da origen es transmisible por causa de muerte, porque el derecho a resarcimiento económico lo incorporó a su patrimonio antes de fallecer, no siendo necesario que la víctima piense en ejercer la acción, como lo exigió la Corte de Apelaciones al pronunciarse previamente. $\mathrm{Y}$ al no probar la diligencia debida,

\footnotetext{
${ }^{81} \mathrm{La}$ Corte Suprema conoce de casación en el fondo, en donde en audiencia de conciliación se acuerda pagar por parte de la demandada subsidiara el pago total de 4.000.000.- no reconociendo responsabilidad en el accidente del trabajo. Mientras que -el demandado principal, empleador contratista, sin reconocer sus responsabilidades en el hecho acuerda pagar 64 cuotas mensuales de 4 Unidades de Fomento.

82 26.11.07. M. Amestoy Klenner y otros con Transportes Calafquén Limitada y otro. $\mathrm{N}^{\circ}$ LegalPublishing: 37723.

83 “... aunque exista entre esa acción y el resarcimiento pretendido, que es de carácter pecuniario, un estrecho e indesmentible vínculo, por cuanto este último se genera y justifica en la aflicción del trabajador afectado, lo que le imprime el carácter de personalísima a la acción de que se trata, el que no logra desvirtuarse con el hecho que dé lugar a un crédito en dinero...". -Considerando noveno-.

${ }^{84}$ Por lo que el objetivo del resarcimiento se cumple en este caso, si y solo si, cuando la "... reparación es entregada al que padeció dolor, la molestia o aflicción en sus sentimientos o facultades espirituales...”. -Considerando noveno-, aplicando armónicamente lo presupuestado en el artículo 88 de la Ley $\mathrm{N}^{\circ} 16.744$, el cual dispone que los derechos concedidos por la ley son personalísimos e irrenunciables.

${ }^{85}$ No sería sancionatorio, a pesar que provenga del incumplimiento del deber de protección del empleador para con el trabajador, pues, en caso poseer el carácter de sancionatorio, abriría la posibilidad de deducir la acción en calidad de iure hereditatis, lo cual "...llevaría también al absurdo de admitir que quien pierde la vida en determinadas circunstancias tiene el derecho a ser reparado por ello y, a su vez, lo transmite a terceros, todo lo cual no se condice con la naturaleza de la acción de que se trata". -Considerando décimo-.

${ }^{86}$ El Primer Juzgado de Letras del Trabajo de Valdivia, con fecha 21 de julio de 2006, rol No 935-2005, acogió la demanda presentada por la parte demandante, en su calidad de heredera de un trabajador fallecido a causa de un disparo producto de un asalto mientras cumplía sus funciones laborales, condenando a la demandada principal y subsidiariamente a la Cervecera CCU Chile Limitada, a pagar a los demandantes, como herederos del trabajador fallecido, a título de indemnización por daño moral, la cantidad de $\$ 35,000.000$. - La Corte de Apelaciones de Valdivia, por su parte, se manifestó contraria a la tesis de la transmisibilidad, revocando el fallo de primera instancia, fundando en sus considerandos quinto y sexto que el trabajador sobrevivió con cierto grado de conciencia algunos segundos y que el derecho a pedir indemnización de perjuicios por daños extrapatrimoniales "...es personalisimo y no se comprende dentro de aquellos que el de cujus (sic) puede transmitir por herencia...", como también la improcedencia de presumir que el herido hubiere “...pensado en tal acción judicial reparatoria en el brevísimo tiempo en que estuvo consciente...".
} 
el empleador debería resarcir los perjuicios, en este caso, el del daño moral transmitido a sus herederos.

Sin perjuicio de lo anterior, no deja de ser interesante el fundamento del tribunal $a$ quo a favor de la transmisibilidad, al señalar que a los herederos del trabajador fallecido les fue transmitido el derecho a ejercer la acción indemnizatoria conforme al artículo 69 letra b) de la ley de accidentes y enfermedades profesionales ${ }^{87}$, y por tanto, estimó que el accidente produjo una afectación sicológica y moral, producto del disparo recibido por el trabajador, y que este tuvo una clara conciencia de la gravedad de su lesión, provocándole “...intranquilidad y desesperación...”-Considerando Decimocuarto-y por consecuencia, el sufrimiento del daño moral ${ }^{88}$.

7) Por último, ya con el Nuevo Procedimiento Laboral en funcionamiento que, la Corte de Apelaciones de Punta Arenas, rol 19-2008 ${ }^{89}$, señaló que el daño moral no es transmisible a los herederos del trabajador fallecido y que por tanto, deberán accionar en calidad de iure propio en sede civil, pues, la pretensión se sustenta en el sufrimiento moral de la víctima, no pudiendo ser deducida sino por su titular, y que en el caso que haya fallecido, la acción de indemnización es intransmisible a sus herederos. Negando la existencia de vinculo alguno entre el empleador y los herederos del fallecido trabajador ${ }^{90}$.

\section{CIRCUNSTANCIAS QUE ALTERAN LA TRANSMISIBILIDAD}

La doctrina ha planteado que el carácter personalísimo de la acción no es admitido de forma uniforme, ello por el contenido económico de la misma, pues como es evidente -y salvo que la parte demandante solicite una suerte de disculpas verbales y públicas en caso de injuria o calumnia en cuanto al derecho al honor- que la reparación misma del dańo moral ocasionado al de de cujus se traduce en una indemnización de carácter pecuniaria ${ }^{91}$.

Sin embargo, como ya hemos señalado, los argumentos que niegan la tesis de la transmisibilidad $^{92}$, se refieren principalmente a que el daño moral no pierde su carácter de dere-

\footnotetext{
87 Continúa el razonamiento del tribunal en cuanto a que, “...por rápida que haya sido la muerte, ha transcurrido un instante de razón, por breve que haya sido, entre la herida recibida y la muerte, suficiente para que se haya experimentado un dolor y para que nazca, en el patrimonio de la víctima un crédito de indemnización..." y por tanto, los herederos al accionar contra el empleador, están reclamando la reparación del perjuicio sufrido por el trabajador vivo que luego falleció, transmitiéndose la acción.

${ }^{88}$ El monto en primera instancia fue de $\$ 35.000 .000$. Sin embargo, ni la Corte de Valdivia, ni la Corte Suprema adscribieron a la tesis de la transmisibilidad.

89 Punta Arenas, 23 de diciembre de 2008, Corte Apelaciones de Punta Arenas, rol 19 2008. María Inés Lavadie Saldivia y otros con Bore y Cerda Limitada. No LegalPublishing: 41463.

${ }^{90} \mathrm{El}$ razonamiento de la Corte es poco feliz pues la parte demandante desde un principio planteó su acción en calidad de iure bereditatis, a lo cual dicha Corte, no se pronuncia por la transmisibilidad de la acción a los herederos propiamente tal, sino que solo se manifiesta en relación a la existencia o no del vínculo contractual previo entre la cónyuge y los hijos del trabajador fallecido y el empleador; vínculo que, por lo demás, no existe si se actúa en calidad de iure propio. Lo cual nos demuestra nuevamente la poca acuciosidad que, previa a la reforma al nuevo procedimiento laboral, era demostrada por nuestra Excelentísima Corte Suprema y que ahora vemos lamentablemente en este tribunal de alzada

${ }^{91}$ Cfr. DOMfNGUEZ, C., op. cit. (n. 19), p. 731. Y ello, como ya hemos señalado anteriormente, es apoyado por la doctrina clásica nacional, véase ALESSANDRI, A., op. cit. (n. 13), pp. 467 y ss. También existe un apoyo de la doctrina francesa, véase: MAZZAUd, H. y TunC, A., op. cit. (n. 24), pp. 535 y ss.

92 Cfr. BARROS, E., op. cit. (n. 32), pp. 945 y ss.
} 
cho personalísimo, no obstante que el hecho mismo da derecho a un crédito en dinero 93 . En cuanto a la finalidad de la indemnización perseguida, lo que se persigue es la compensación por el daño ocasionado a la víctima, de forma personal.

A nuestro juicio, la doctrina que propugna la tesis de la intransmisibilidad, la cual no compartimos ya que desde el punto de vista adjetivo, la acción de perjuicios nace a consecuencia del incumplimiento de un contrato y tiene por objeto reparar el daño causado, materializándose de ese modo la responsabilidad contractual, siendo la acción personal, mueble y patrimonial -por tanto transmisible-, sustenta su posición producto de un temor muy claro, cual es, la posibilidad de la concurrencia del cúmulo de acciones, dándose la posibilidad que una persona accione paralelamente en sede contractual en calidad de iure hereditatis por el daño moral ocasionado al de de cujus y en sede extracontractual en calidad de iure propio por el daño moral que le produjo a consecuencia de la muerte la persona con la cual tenía alguna cercanía ${ }^{94}$.

Por su parte, el Derecho argentino, aplicando el artículo 1099 de su Código Civil ${ }^{95}$, contempla que la acción por daño moral solo se transmite a los herederos cuando el causante-damnificado la hubiese entablado, estando legitimados activamente los herederos para continuar la acción: "La ley consagra, de tal modo, el principio de la intransmisibilidad hereditaria de la acción por daño moral, con la sola excepción indicada en el artículo 1099 del Cód. Civil"96. Sus fundamentos, entre otros, al igual que la doctrina nacional chilena que plantea la tesis de la intrasmisibilidad, es el del carácter personalísimo que tiene el derecho moral, "...que se trasladaría a la acción resarcitoria tornándola insusceptible de ser ejercitada por terceros" 97 .

Pero esta solución, de carácter netamente civilista -al igual que lo señalado por la tesis del profesor Domínguez Águila-, no comprende la naturaleza misma del accidente del trabajo o de la enfermedad profesional acaecida por el incumplimiento, por parte del em-

\footnotetext{
${ }_{93}$ El propio Domínguez Águila ha concluido que “...la transmisibilidad de la acción reparatoria por daño patrimonial a sus herederos no tiene fundamentos serios...". Véase DOMINGUEZ, R., "Sobre la transmisibilidad... (n. 12), p. 513. Además de ello, dicho autor sostiene que, sin perjuicio de que en el daño patrimonial la acción para su indemnización sea transmisible, por cuanto la indemnización vendría a sustituir o reemplazar por equivalencia el bien dañado -bien este último incorporado al patrimonio del causante-, en cuanto al daño extrapatrimonial, la finalidad que persigue la indemnización en ese caso tiene un carácter totalmente diferente al de sustituir o reemplazar, de modo que el carácter patrimonial de la indemnización no demostraría su transmisibilidad.

${ }^{94}$ Interesante es el reciente artículo del profesor Corral Talciani, el cual analiza la situación de concurrencia de acciones de responsabilidad contractual y extracontractual. Para mayor abundamiento véase CORRAL, H., "Concurrencia de acciones de responsabilidad civil contractual y extracontractual en los daños causados por accidente del trabajo", en: Revista Chilena de Derecho Privado, $\mathrm{N}^{\circ} 14$, julio 2010, pp. 69-107.

95 Artículo 1099 del Código Civil argentino: "Si se tratare de delitos que no hubiesen causado sino agravio moral, como las injurias o la difamación, la acción civil no pasa a los herederos y sucesores universales, sino cuando hubiese sido entablado por el difunto".

${ }^{96}$ Pizarro, R. Daño moral. Prevención. Reparación. Punición. El daño moral en las diversas ramas del derecho $-1^{2}$ edición-. Buenos Aires: Editorial Hamurabi SRL, 1996, pp. 244-245.

${ }^{7} \mathrm{Ibid}$. De contemplar en nuestra legislación una norma similar a la argentina, dilucidaría un tanto la situación que se presenta en cuanto a la transmisibilidad, pero de todas formas dejaría abierta la posibilidad que, presentada la demanda y fallecido la víctima con posterioridad a ella, los sucesores obtengan incremento de su patrimonio a través de la indemnización de los cuales son herederos, y eventualmente según corresponda, de la indemnización solicitadas por el daño propio ocàsionado por la muerte del causante.
} 
pleador, del artículo 184 del CT, como ya hemos señalado reiteradamente en este estudio, se entiende incorporado al contrato de trabajo. La jurisprudencia analizada, casi en su totalidad, se ha manifestado en primera y segunda instancia a favor de la transmisibilidad de la acción por daño moral, siendo casadas por la nuestro Máximo Tribunal, salvo una que otra jurisprudencia que escapa al criterio de aplicación en cuanto a la intransmisibilidad.

Sin perjuicio de lo señalado por la jurisprudencia ${ }^{98}$-la cual interpretando armónicamente los artículos 88 y 69 letra b) de la Ley $\mathrm{N}^{\circ} 16.744$ concluye que los derechos concedidos por dicha ley son personalísimos y que la acción por daño moral sería intransmisible-, creemos para interpretar el artículo 69 se debe aplicar el principio pro operario, siendo competente el tribunal laboral para conocer de la acción por daño moral, esto de acuerdo al artículo 420 letra f) del CT. Que el artículo 69 es una norma adjetiva dentro de una ley que contempla derechos subjetivos públicos, como lo es el seguro social, pero que ello no limita, de acuerdo a los principios del derecho del trabajo, tratados y convenios internacionales, como también en la Constitución Política de la República, ni tampoco exime de la responsabilidad que le cabe al empleador que, por su culpa o dolo, ocasionó el accidente o enfermedad profesional que devino en la muerte del trabajador y la consecuente acción impetrada por sus herederos.

Sin embargo, debemos distinguir las diferentes circunstancias que alterarían la transmisibilidad de la acción, teniendo como presupuesto siempre que, la acción por daño moral, al igual que la acción de perjuicios que procura indemnizar el daño patrimonial, es transmisible. Pues si bien el daño moral es un derecho personalísimo, pero su acción patrimonial es transmisible, como lo veremos a continuación.

En cuanto a las circunstancias que alterarían la transmisibilidad, podemos visualizar las siguientes situaciones:

a) No hay duda en el caso del trabajador afectado por un accidente o una enfermedad profesional y que haya accionado por daño moral transmite a sus herederos su acción si fallece antes de conocer una sentencia definitiva. Esto por aplicación netamente de normas de derecho sucesorio y de representación contempladas en el Código de Procedimiento Civil.

b) Tampoco habría dudas en que el trabajador que ha tenido un accidente del trabajo fallece con posterioridad y a causa de él y que no haya accionado contra su empleador. Es transmisible porque tanto el daño moral como la acción de daño moral nacieron y se incorporaron en el patrimonio del causante, y salvo renuncia expresa, no podríamos suponer que ha perdonado el daño que le causó el incumplimiento del empleador. Esta posición es aplicable a su vez a las enfermedades profesionales, pues por su naturaleza, y a diferencia de los accidentes del trabajo que ocurren de forma repentina e inmediata, las enfermedades se producen lenta y paulatinamente.

\footnotetext{
98 Concepción, 12 de diciembre de 2007, Corte de Apelaciónes de Concepción, 423 2007. Elizabeth del Carmen Huentemil Fuentes y otros con Agro Inversiones S.A. N LegalPublishing 37966.
} 
c) El problema de la muerte instantánea sigue siendo complejo, pues tendríamos que optar entre si aceptamos o no la existencia del daño moral en el instante mismo de la muerte y de si descartamos por completo la transmisibilidad, pues al dejar de existir la persona, no hubo instante alguno en que existió el daño y el consecuente derecho de acción de perjuicios. Si bien debemos tener en cuenta lo señalado por la doctrina francesa ${ }^{99}$, proponemos accionar por los daños propios provenientes del delito civil, fundamentado también en el incumplimiento de la obligación legal del artículo 184 del CT, norma denominada de orden público.

d) Frente a la pregunta de que si ¿es posible ceder entre vivos la acción por daño moral? Una primera aproximación nos llevaría a distinguir si lo realiza la víctima directa en vida -lo cual degeneraría en un pacto sobre sucesión futura, adoleciendo de objeto ilícito- o realizado por los herederos. Sin embargo, existe una doctrina minoritaria que plantea la transmisibilidad amplia por actos entre vivos del derecho a la reparación del daño moral ${ }^{100}$, análisis el cual, si bien creemos necesario señalar, escapa a efectos de este estudio.

\section{PROPUESTA DE LEGE FERENDA EN BÚSQUEDA DE SEGURIDAD JURÍDICA}

Que existe una doble dualidad para este tema en particular. En primer lugar, la dualidad que dice relación con dos regímenes de responsabilidad, con consecuencias totalmente diferentes, que pueden conocer frente a un caso particular. Dicha dualidad trae como consecuencia negativa la concurrencia de acciones para un mismo hecho, cual es, el accidente o enfermedad profesional del trabajador ${ }^{101}$. Y que dichas acciones, al impetrarse en tribunales distintos, acreditando calidades jurídicas diferentes, pero derivados desde el mismo hecho que les dio inicio, puede acarrear que en un caso no se dé cuenta de la ocurrencia del accidente o enfermedad, y en otro tribunal se acoja la respectiva demanda, trayendo como consecuencia sentencias contradictorias frente a un mismo hecho. Un reciente estudio sobre la materia propone la revisión del artículo 420 del CT y plantea que los tribunales laborales debieran conocer de todas las acciones que se deriven de daños causados por un accidente del trabajo, independiente si es responsabilidad contractual o extracontractual ${ }^{102}$.

Que la segunda dualidad se da con la existencia de normas de derecho laboral y seguridad social, como también normas del derecho civil, haciendo un tanto más complicada la situación, pues la interpretación también variará de tribunal en tribunal por la sencilla razón de la existencia de dos jueces con especialidades diferentes, los cuales interpretan, querámoslo o no, con aplicación de los principios de cada rama del derecho que le corresponda.

\footnotetext{
99 "... ¡quién no advierte lo que habría de chocante en no conocer ninguna reparación de tal perjuicio! Cuando la víctima no haya sobrevivido, eso sería liberar al responsable de toda acción ejercitada por los herederos en su carácter de causahabientes; ya que como se ha dicho, la víctima, en el caso de muerte instantánea, no sufre otro daño. Eso sería darles así una prima a los imprudentes o a los homicidas que golpean con más fuerza; si su víctima muere en el acto, aquellos ven que se desvanece la acción de los herederos...". Véase MAZZAud, H. y TuNC, A., op. cit. (n. 24), p. 542.

100 PIZARRO, R., op. cit. (n. 96), pp. 253 y ss.

${ }^{101}$ Cfr. Barros, E., op. cit. (n. 32), pp. 1055 y ss.

${ }^{102}$ Cfr. Corral, H., "Concurrencia de acciones... (n. 94), p. 107.
} 
Que justamente producto de la insuficiencia del derecho civil para contemplar la cuestión social $^{103}$, se ha ido creando el derecho del trabajo como una rama autónoma, especial e independiente, estableciendo los mecanismos limitantes a la autonomía de la voluntad producto de la situación de desigualdad entre empleador y trabajador, a diferencia de la igualdad de partes supuesta por el derecho común al momento de pactar ${ }^{104}$.

Sin embargo, frente a la autonomía del derecho del trabajo, la problemática de la responsabilidad del empleador por culpa o dolo frente a un accidente o enfermedad profesional, y en particular, con la muerte del trabajador y la posibilidad de transmisibilidad de las acciones posteriores a sus herederos, la doctrina del derecho del trabajo no ha presentado un desarrollo desde su propia rama ${ }^{105}$. Y es dicha autonomía la cual se vuelve relativa ${ }^{106}$ enfrentada a lagunas que presente la legislación especial laboral.

Que la consecuencia más grave de esta doble dualidad, es la posibilidad de una doble indemnización por parte de los herederos, pues no hay norma expresa que prohíba lo uno o lo otro, es decir, actuar bajo una u otra calidad. Justamente por lo anterior, que la primera propuesta de lege ferenda es la existencia de una norma que excluya, cuando se ha presentado acción de perjuicios en alguna de las dos calidades - de iure propio o de iure hereditatis- la posibilidad de accionar, tanto paralelamente, como con posterioridad al fallo de la inicial demanda. Con esto, solucionaremos dicha problemática, incluyendo, en la actual Ley $N^{\circ} 16.744$, en el artículo 69, al final "No obstante a lo anterior, cualquier acción impetrada, y en cualquier calidad, sea de iure propio o de iure hereditatis, y ya sea en sede contractual o extracontractual, excluirá de plano a la otra"107.

Sin embargo, y de acuerdo a lo analizado con ocasión de esta investigación, una propuesta de lege ferenda acorde a la dispar jurisprudencia y duplicidad de competencia de tribunales, sería la de plantear una regulación orgánica sobre la responsabilidad que le cabe al empleador en caso de que por culpa o dolo, ocasione perjuicios tanto al trabajador como a terceros. Fijando con claridad el tribunal competente, que por cuanto el artículo 184 del CT es una obligación de carácter legal deberían ser competentes los Tribunales Laborales

\footnotetext{
103 MaNGarelli, C. "El derecho del trabajo y su relación con el derecho civil”, en: Biblioteca Juridica Virtual del Instituto de Investigaciones de la Universidad Autónoma de México, pp. 105-123. http://www.juridicas.unam.mx/publica/librev/rev/revlads/ cont/7/art/art5.pdf [consultado el 12 octubre 2009].

${ }^{104}$ Es por ello que frente a conflictos con principios del derecho común, el derecho del trabajo y la seguridad social, por su carácter de especial, primarán estos últimos por cuanto se hace aplicable el lex specialis derogat generalis.

$105 \mathrm{Si}$ bien abunda la doctrina y el trabajo arduo de los tribunales especiales del trabajo, son civilistas quienes han estudiado con mayor profundidad esta problemática.

106 Interesante es el análisis que realiza Cristina Mangarelli afirmando el alcance de la autonomía por parte de la rama del derecho del trabajo. Sin perjuicio de esto, la doctrina comparada ha señalado que "la aplicación de normas civiles en la disciplina laboral se realizará solo ante un vacío de la norma laboral y siempre que el concepto civil que se pretende aplicar no vulnere normas, conceptos o principios del derecho del trabajo. MANGARELli, C., op. cit. (n. 103), p. 105.

107 Esta propuesta no contradice a la tendencia que ha tenido en particular esta rama del derecho en relación a la protección de la pareja de hecho del trabajador fallecido - por ejemplo la pareja con el cual convivió, tuvo hijos, pero no pudo lograr o simplemente no quiso contraer matrimonio civil-. Esperemos que -así como el Derecho del Trabajo ha sido pionero en este tipo de protecciones, como también en la del reconocimiento del daño moral en sede contractual-sea una rama primeriza en proyectar una solución a personas en situación de uniones de hecho, solo por dar un ejemplo. De todas formas es lejana a esta investigación proponer una reforma a las instituciones del derecho sucesorio en general, y en particular, a ciertos derechos y situaciones acordes al contexto en que se desenvuelve nuestra sociedad.
} 
por la infracción al deber por parte del empleador; el procedimiento; la carga probatoria, los plazos de prescripción, y que en el caso que se quiera hacer valer los derechos vulnerados por un delito o cuasidelito, la sola presentación de la demanda por ese hecho, excluya con posterioridad a demandar al mismo empleador en sede laboral.

Para evitar cualquier conflicto eventual que diga relación con el carácter personalísimo de la acción por daño moral, el artículo 88 de la Ley $N^{\circ} 16.744$ debería señalar de lege ferenda: "Los derechos concedidos por la presente ley son personalísimos e irrenunciables, salvo el derecho a accionar entregada en el artículo 69 de esta ley".

\section{CONCLUSIONES}

1) En cuanto a la transmisibilidad, resulta mucho más acabado el análisis que se ha hecho desde la óptica del derecho común. Esta doctrina aboga por la transmisibilidad de la acción, de forma relativa caso a caso, con asidero jurisprudencial hasta hace unos años. Los jueces la aceptan, en su mayoría, al reconocer la competencia absoluta y la titularidad activa fundándose, entre otras normas, en el artículo 1097 del C. Civil.

2) La intransmisibilidad propone que frente al fallecimiento de la víctima, se opte por la vía extracontractual (de iure propio) declarando improcedente la vía contractual en calidad de iure hereditatis.

3) Al igual que frente al daño moral, la doctrina laboralista no ha realizado un estudio del todo acabado ni contempla posiciones doctrinales claras, salvo algunos pronunciamientos de autores que tangencialmente se ha referido a la problemática de la transmisibilidad, cuando han tenido que abordar la situación de la competencia de los tribunales del trabajo.

4) Tanto quienes apoyan la tesis de la transmisibilidad en materia laboral, como quienes la rechazan, no han visualizado la tendencia que ha seguido la doctrina del derecho común, aceptando o rechazando, pero no considerando los avances que ha tenido la doctrina del derecho común.

5) La solución, más que por hacer interpretaciones restrictivas de las normas en comento, debe apuntar a una interpretación armónica teniendo presente los tratados y convenios internacionales, las normas constitucionales, la normas legales, y por sobre todo, los principios propios del derecho del trabajo y la seguridad social, ello por tratarse de una rama independiente y autónoma con características propias distinto del derecho común.

6) En cuanto a la jurisprudencia analizada, la teoría de la transmisibilidad es aceptada por jueces de fondo, a veces expresa y otras veces tácitamente. En las Cortes de Apelaciones muy pocas veces se cuestiona la legitimidad activa en cuanto a la transmisibilidad confirmando, por regla general, la sentencia del tribunal a quo.

7) La Corte Suprema hoy en día no acepta la tesis de la transmisibilidad, afirmando que el daño moral tiene un carácter personalísimo que hace que la acción de perjuicio tome dicho carácter también y así no puede ser transmitido, ni menos transferido a terceros. 
8) En caso de muerte del trabajador, hay que distinguir distintas circunstancias. Es transmisible: cuando el trabajador interpuso demanda y fallece antes de conocer la sentencia definitiva; en los casos de enfermedad profesional, por su naturaleza lenta y paulatina, y en lo accidentes en que el trabajador muere, pero con posterioridad a ello. No es transmisible en la muerte instantánea. Y que no es posible la cesión entre vivos.

\section{BIBLIOGRAFÍA}

Alessandri Rodrfguez, A. De la responsabilidad extra-contractual en el Derecho Civil Chileno. Tomo II -2a edición-. Santiago: Ediar Editores LTDA., 1983.

BARRIENTOS ZAMORANO, M. "La transmisibilidad de la acción por daño moral en el Derecho privado europeo", en: La Semana Jurídica, N 218, 10 al 16 enero de 2005, pp. 14-16.

Barros Bourie, E. Tratado de responsabilidad extracontractual. Santiago: Editorial Jurídica de Chile, 2006.

CÁRDENAS VILlareal, H. "Dàno moral por incumplimiento de contrato: un réquiem por una uniformidad jurisprudencial", en: Revista Chilena de Derecho, vol. 33 № 3, pp. 585-593. Santiago: Pontificia Universidad Católica de Chile, 2006.

CORRal TAlCiani, H. Lecciones de responsabilidad civil extracontractual. Santiago: Editorial Jurídica de Chile, 2003.

Corral Talciani, H., "Concurrencia de acciones de responsabilidad civil contractual y extracontractual en los daños causados por accidente del trabajo", en: Revista Chilena de Derecho Privado N 14, julio 2010, pp. 69-107.

DIEZ SCHWERTER, J. "Víctimas directas y por repercusión derivada de accidentes del trabajo o enfermedades profesionales en nuestra jurisprudencia reciente: del problema de la competencia a las distorsiones sustanciales", en: Revista de Derecho No 214, año LXXI, pp. 65-79. Concepción: Universidad de Concepción, julio-diciembre, 2003.

DIEZ SCHWERTER, J. "Víctimas directas y por repercusión en la responsabilidad civil derivada de accidentes del trabajo o enfermedades profesionales en nuestra jurisprudencia reciente: del problema de la competencia a las distorsiones sustanciales", en: VARAS BRAUN, Juan A. y TURNER SAELZER, Susan (coord.). Estudios de Derecho Civil. Jornadas Nacionales de Derecho Civil. Valdivia 2005. Santiago: LexisNexis, 2005, pp. 563-583.

DIEZ SCHWERTER, J. "La culpa del empresario por accidentes del trabajo: modernas tendencias jurisprudenciales", en: BARAONA GONZÁLEZ, Jorge y ZELAYA ETCHEGaraY, Pedro (editores). La responsabilidad por accidentes del trabajo. Cuadernos de Extension Juridica $\mathrm{N}^{\circ} 10$, pp. 73-98. Santiago: Universidad de los Andes, 2005.

DIEZ SCHWERTER, J. "Responsabilidad civil derivada de accidentes del trabajo y enfermedades profesionales: aspectos relevantes de su regulación y operatoria actual", en: Revista de Derecho $\mathrm{N}^{\circ} 21$, pp. 163-185. Valparaíso: Pontificia Universidad Católica de Valparaíso, $2^{\circ}$ semestre, 2008.

Domínguez ÁguiLA, R. "Comentarios de Jurisprudencia 1. Competencia civil para el conocimiento de la acción indemnizatoria del daño moral sufrido por causahabientes del trabajador", en: Revista de Derecho $\mathrm{N}^{\circ}$ 211, año LXX, pp. 357-372. Concepción: Universidad de Concepción, enero-junio, 2002.

Domfnguez Águila, R. "Sobre la transmisibilidad de la acción por daño moral", en: Revista Chilena de Derecho, vol. $31 \mathrm{~N}^{\circ} 3$, pp. 493-514. Santiago: Pontificia Universidad Católica de Chile, 2004.

Domínguez Águila, R. "Por la intrasmisibilidad de la acción de daño moral", en: VARAS BRaun, Juan A. y TURNer SAElzer, Susan (coord.). Estudios de Derecho Civil. Jornadas Nacionales de Derecho Civil. Valdivia 2005. Santiago: LexisNexis, 2005, pp. 607-633. 
Domínguez Benavente, R. y Domínguez Águila, R. "Comentarios de Jurisprudencia. 1. Daño moral en la responsabilidad contractual. Ausencia de norma excluyente de su reparación", en: Revista de Derecho $\mathrm{N}^{\circ}$ 196, año LXII, pp. 155-160. Concepción: Universidad de Concepción, julio-diciembre, 1994.

Domínguez Hidalgo, C. El Daño Moral. 2 tomos. Santiago: Editorial Jurídica de Chile, 2000.

GumUCio RIVAS, J. "Responsabilidad civil del empleador por accidentes del trabajo en Chile", en Revista Laboral Chilena, $\mathrm{N}^{\circ} 12$, diciembre 1996, pp. 62-71.

GUMUCio RIVAS, J. "Responsabilidad civil del empleador por daños derivados de Accidentes o Enfermedades profesionales de sus dependientes: Problemas que genera la teoría dualista en la legislación chilena en materia de competencia", en: Revista Laboral Chilena $\mathrm{N}^{\circ} 5$, mayo de 1999, pp. 53-59.

LAGOS VILLARREAL, O. "¿Hacia una objetivación jurisprudencial de la responsabilidad patronal? Criterios para evaluar sus consecuencias", en: GUZMÁn BRITO, A. (Editor científico). Estudios de Derecho Civil III. Valparaíso 2007. Santiago: LegalPublishing, Santiago, 2008, pp. 846-865.

Mazzaud, H. y TUNC, A. Tratado teórico y práctico de la responsabilidad civil delictual y contractual, tomo II, volumen II. Buenos Aires: Ediciones Jurídica Europa-América, 1978.

Pizarro, R. Daño moral. Prevención. Reparación. Punición. El daño moral en las diversas ramas del derecho $-1^{\text {a }}$ edición-. Buenos Aires: Editorial Hamurabi SRL, 1996.

Ramf́reZ LaRenas, M. Transmisibilidad de la acción por daño moral. Un estudio comparativo entre Chile y España. Tesis. Talca: Universidad de Talca, 2004.

RODRfGUEZ GREZ, P. Responsabilidad Extracontractual. Santiago: Editorial Jurídica de Chile, 1999.

VERDUGO ERNST, L. "La responsabilidad del empleador en los accidentes del trabajo o enfermedades profesionales", en: Revista Laboral Chilena N 1, enero 1997, pp. 65-68.

Walter Diaz, R. y Lanata Fuenzalida, G. Régimen legal del Nuevo Proceso Laboral Chileno. Santiago: LegalPublishing, 2009.

\section{SITIOS WEB CONSULTADOS}

MANGARELLI, C. "El derecho del trabajo y su relación con el derecho civil", en: Biblioteca Jurídica Virtual del Instituto de Investigaciones de la Universidad Autónoma de México, pp. 105-123. http://www.juridicas. unam.mx/publica/librev/rev/revlads/cont/7/art/art5.pdf [consultado en octubre de 2009].

http://www.ben.cl [consultado entre meses septiembre-octubre de 2009].

http://www.legalpublishing.cl [consultado entre meses agosto-diciembre 2009].

http://www.poderjudicial.cl [consultado entre meses noviembre de 2009 y enero de 2010]. 